\title{
THE VALUATION OF INITIAL SHARE PRICE USING THE FREE CASH FLOW TO FIRM METHOD AND THE REAL OPTION METHOD IN INDONESIA STOCK EXCHANGE
}

\author{
Adhy Listya Paramitha \\ Sri Hartoyo \\ Nur Ahmad Maulana \\ Business Management Post Graduate Program Institut Pertanian Bogor \\ Raya Pajajaran Street, Bogor 16143 \\ Email: tya.paramitha@gmail.com
}

\begin{abstract}
The purposes of this study were to determine fair share value, to analyze the factors that influence undervalue and overvalue, and to determine the best valuation method. This study made valuation using real options method and free cash flow to firm method. The results of partial logistic regression on Free Cash Flow to Firm showed that tenor variable and equity variable had positive and significant effects, while dummy variable had a negative and significant effect. In the real option model, tenor variable and implied volatility variable had positive and significant effects, while sheets of share variable had a negative and significant effect
\end{abstract}

Keywords: IPO, Free Cash Flow to Firm, Real Option

\begin{abstract}
Abstrak
Tujuan dari penelitian ini adalah menentukan nilai harga wajar saham emiten, menganalisis faktor yang menentukan undervalue dan overvalue serta menentukan metode valuasi terbaik. Penelitian ini menggunakan valuasi harga saham dengan metode real option dan free cash flow to firm. Hasil regresi logistik pada FCFF secara parsial, variabel tenor dan ekuitas berpengaruh positif dan signifikan, sedangkan variabel dummy berpengaruh negatif dan signifikan. Pada model real option, variabel tenor dan implied volatility berpengaruh positif dan signifikan, sedangkan variabel lembar saham berpengaruh negatif dan signifikan.
\end{abstract}

Kata Kunci: IPO, Free Cash Flow to Firm, Real Option

\section{INTRODUCTION}

The determination of initial share price becomes the chief concern of financial analysts since it correlates with the success or failure of initial public offering. If an initial public offering gains oversubscribe, it can be considered successful because the amount of shares required by investors is larger than the amount of shares offered by the company. But company owners usually wish to minimize undervalue, since undervalue will cause transfer of wealth from owner to investor (Daljono, 2000). The performances of companies which experienced undervalue and overvalue are shown in Table 1.

The methods commonly used by emitents and financial analysts in making valuation of initial share price or initial public offering and in predicting the tendency of prices after being registered in the stock exchange are conventional methods, namely discounted cash flow (DCF) and relative valuation (RV). These methods are commonly used by emitents who want to register their shares in Indonesia Stock Exchange. Both methods have not yet been able to predict the offered initial share price fairly. This happens because empirically the greater part of the shares, which are valuated using the conventional methods, after initial public offering in Indonesia Stock Exchange tend to undervalue.

The relatively large undervalue on first day registration is very unfavorable for involved parties such as emitents, underwriters, and investors. The undervalue causes declining returns for emitents. For underwriters, a lower price in initial public offering means a lower income. However, a lower share price 
Table 1. The Performances of Companies which Carried Out Initial Public Offering (IPO) During Year 2008-2012

\begin{tabular}{|c|c|c|c|c|c|c|c|}
\hline \multirow{2}{*}{$\begin{array}{l}\text { Year } \\
2008\end{array}$} & \multirow{2}{*}{$\begin{array}{c}\text { Number of IPO } \\
19\end{array}$} & \multicolumn{2}{|c|}{ Undervalue } & \multicolumn{2}{|c|}{ Overvalue } & \multicolumn{2}{|c|}{ Fairly price } \\
\hline & & 15 & $78.95 \%$ & 4 & $21.05 \%$ & - & $0.00 \%$ \\
\hline 2009 & 13 & 7 & $53.85 \%$ & 5 & $38.46 \%$ & 1 & $7.69 \%$ \\
\hline 2010 & 23 & 21 & $91.30 \%$ & 2 & $8.70 \%$ & - & $0.00 \%$ \\
\hline 2011 & 25 & 18 & $72.00 \%$ & 7 & $28.00 \%$ & - & $0.00 \%$ \\
\hline 2012 & 22 & 20 & $90.91 \%$ & 1 & $4.55 \%$ & 1 & $4.55 \%$ \\
\hline Total & 102 & 81 & & 19 & & 2 & \\
\hline Percent: & & $79.41 \%$ & & $18.63 \%$ & & $1.96 \%$ & \\
\hline
\end{tabular}

means a bigger chance for the shares to be sold out. On the other hand, investors can be trapped by the assumption that all fair share prices are undervalue, while in reality not all share prices in initial public offering are undervalue and bring loss when investors buy the shares.

Thus, there are problems in determining share price in initial public offering. The conventional methods employed by emitents are not able to determine share prices correctly. In this case, the real option method and free cash flow to firm method are expected to determine initial share prices correctly. The factors used in these methods consist of two parts. First, the fundamentals of the company (equity, asset, debt, tenor, implied volatility, number of share sheets) since they comprise the company's whole va-lue. Second, macroeconomic factors (Jakarta Inter Bank Offering Rate (JIBOR), crisis, inflation, ex-change rate and gross domestic product) to find out the impact of macroeconomic factors on share price.

Then we could make several problem formulations such as followed: What was the value of the fair initial share price of the emitents listed in Indonesia Stock Exchange during year 2008-2012, when analyzed with the real option method and the free cash flow to firm method? Could the overvalue and undervalue of share price in initial public offering be predicted by employing independent variables such as asset, debt, tenor, JIBOR, implied volatility and the sheets of share? Was there any difference between the real option method and the free cash flow to firm method in determining the fair initial share price of the emitents listed in Indonesia Stock Exchange during the year 2008-2012?

From those problem formulations we determined the purposes of this study, namely: 1) To determine the fair share price of emitents who registered their initial public offering in Indonesia Stock Exchange during the year 2008-2012, by using the real option method and the free cash flow to firm method. 2) To analyze the factors which influenced undervalue and overvalue in initial public offering. 3) To find out the best valuation method to determine the fair initial share price of emitents who registered their initial public offering in Indonesia Stock Exchange during year 2008-2012.

\section{THEORETICAL BASE AND HYPOTHESES}

Free cash flow to firm was the available cash for investor after all operational duties (including tax) had been paid, and investments required in running capital and fixed capital had been made. FCFF calculation was the estimation of the company value, so this value had to be subtracted by debt when a company wanted to know the value of its capital. The term "real options" was introduced by Stewart C. Mayers from Massachusetts Institute of Technology (MIT) in 1977. According to Setyabudi (2008), real option method was a method which could explain the value of a company in an uncertainty and regulate flexibility in an investment strategy.

According to Winarno (2011), logit model was a regression model which was used to analyze dependent variable with a probability between 0 and 1 . Logit model was a non-linier regression method which generated an equation in which the dependent variable was categorical. In logit model, dependent variables consisted of binary values such as number 0 and 1 (representing 'yes' and 'no'). The resulting number showed a certain category which resulted from the calculation of the probability of the category's occurence.

The hypotheses of this study were as followed: It was proposed that Asset, Debt, Tenor, Implied Volatility, JIBOR, Public, and Equity influenced the tendency of initial share price to undervalue or overvalue, by employing the real option method and the free cash flow to firm method in Indonesia Stock Exchange. Simultaneous test result could be obtained by considering $p$-value with the following hypothesis: $\boldsymbol{H}_{\boldsymbol{I}}$ : It was proposed that asset, debt, tenor, implied volatility, Jakarta Inter Bank Offering Rate, public and equity simultaneously influenced the tendency of initial share price to undervalue or overvalue, by employing the real option method and the free cash flow to firm method in Indonesia Stock Exchange. 
Partial significance test was made to find out whether an independent variable individually had a significant impact on dependent variable. The criterion of partial hypothesis test was as followed:

$\boldsymbol{H}_{2}$ : It was proposed that asset, debt, tenor, implied volatility, Jakarta Inter Bank Offering Rate, public and equity partially influenced the tendency of initial share price to undervalue or overvalue, by employing the real option method and the free cash flow to firm method in Indonesia Stock Exchange.

\section{RESEARCH METHOD}

The data used in this study was secondary data obtained from companies which had gone public and were registered in Indonesia Stock Exchange during year 2008-2012. During those years there were 102 companies which carried out initial public offering in Indonesia Stock Exchange. With the limitations described previously in this study, we obtained 54 companies to be studied. Data for this study was obtained from Indonesia Stock Exchange during year 20082012. The criteria of selecting the companies to be studied were as followed:

1. The company was registered in Indonesia Stock Exchange during year 2008-2012. Companies which had been registered previously but delisted were not included in this study.

2. Emitents from finance firms and securities firms were not included in this study. The reason of this was because the financial structures of finance firms were different from other companies, while securities firms had more information about initial public offering than other companies.

3. The price registered was the closing price of the first day.

4. The initial public offering used was of companies which registered in Indonesia Stock Exchange for the first time. Companies which bid secondary offering and right issue were not included in this study.

The data processing and analyzing in this study were carried out by employing the share valuation method to calculate the fair value of initial shares of emitents which go public, namely:

\section{Free Cash Flow to Firm Method}

The analysis was carried out through several phases, namely:

1. Calculated the Discount Rate.

The approach used was free cash flow to firm approach, so the discount rate used was weighted average cost of capital (WACC).
2. Made a cash flow projection.

A cash flow projection was made on the components of free cash flow, namely: earning, capital expenditure, and working capital. The FCFF equation was:

$F C F F=E B I T(1-T a x$ Rate $)+$ Depreciation Capital Expenditure - $\triangle$ Working Capital

3. Obtained the terminal value.

Made calculation to obtain the total value of the company. The discount rate employed was cost of capital subtracted by perpetual growth. The terminal value formula used was:

$$
\text { Terminal Value }=\frac{F C F F_{n+1}}{W A C C-g_{n}}
$$

4. Calculated the value of the firm (present value) The value of the firm could be calculated by discounting free cash flow of the firm (FCFF) on weighted average cost of capital (WACC). The formula used was:

Value of the firm =

$\sum_{t=1}^{t=n} \frac{F C F F_{t}}{(1+W A C C)^{t}}+\frac{\left[F C F F_{n+1} /\left(W A C C-g_{n}\right)\right]}{(1+W A C C)^{n}}$

5. Calculated the total equity

Total equity was obtained through the following formula:

Total Equity = Value of the firm - Outstanding debt After the total equity was obtained, the share price was calculated by dividing total equity with the number of shares to be published.

Share price $=$ Total Equity /Outstanding Share

\section{The Real Option Method}

Determining share price in initial public offering by real option method was started by determining variables. The steps were as followed:

1. Calculated the tenor value, by taking the duration average of debt (tenor).

2. Calculated implied volatility. Implied volatility was used for volatility variable whose value was obtained from the calculation using the iteration of Newton-Rhapson. This method had been used by Hakiman (2005), Manaster \& Koehler (1982), and Andi (2010). The price at the initial standard deviation was as followed:

$$
\sigma_{1}^{*}=\left[A B S\left(\ln (\mathrm{V} / \mathrm{D}) r_{f} T\right)(2 / \mathrm{T})\right] 1 / 2
$$

The result of the calculation of the initial standard deviation was calculated further with iteration process in order to obtain implied volatility variable, with the following equation:

$$
\sigma_{i+1}=\sigma_{1}^{*}-\frac{\left[C\left(\sigma_{1}^{*}\right)-C\right] e^{d_{1}^{2 / 2}} \sqrt{2 \pi}}{V \sqrt{T}}
$$


3. Determined the equity value by the Black-Scholes theory with the equation:

Equity value $=V N(d 1) \cdot D e^{-r t} N(d 2)+\varepsilon$

Then the share price in initial public offering could be calculated with the following equation:

Share price $=$ Equity Value $/$ Number of Shares

\section{The Method of Predicting Share Price in Initial Public Offering}

Predicting share price in initial public offering with real option method and FCFF was tested by forming logistic equation where the dependent variable was the binary number 0 and the independent variable was 1 . It was proposed that asset, debt, tenor, implied volatility, JIBOR, public and equity influenced the tendency of initial share price to undervalue or overvalue, by employing the real option method and the free cash flow to firm method in Indonesia Stock Exchange. The formulation of the method was as followed:

$$
\begin{gathered}
L i=\ln \left(\frac{P i}{1-P i}\right)=\beta_{0}+\beta_{1} X_{1}+\beta_{2} X_{2}+\beta_{3} X_{3}+ \\
\beta_{4} X_{4}+\beta_{5} X_{5}+\beta_{6} X_{6}+\beta_{7} X_{7}+\varepsilon
\end{gathered}
$$

In statistical test and variable significance test for logit model there were three estimations which showed that the output of an equation model could be good or bad. The three estimations were partial significance test ( $t$ test), coefficient determination, and simultaneous significance test ( $F$ test).

The result of simultaneous test could be obtained by taking $p$-value with the following hypothesis:

$\boldsymbol{H}_{0}: \beta_{1}, \beta_{2}, \beta_{3,} \beta_{4}, \beta_{5,} \beta_{6}=0$ (asset, debt, tenor, implied volatility, Jakarta Inter Bank Offering Rate, public and equity) simultaneously did not influence the tendency of initial share price to undervalue or overvalue, by employing the real option method and the free cash flow to firm method in Indonesia Stock Exchange.

$\boldsymbol{H}_{1}: \beta_{1,} \beta_{2}, \beta_{3,} \beta_{4}, \beta_{5,} \beta_{6}=0$ (asset, debt, tenor, implied volatility, Jakarta Inter Bank Offering Rate, public and equity) simultaneously influenced the tendency of initial share price to undervalue or overvalue, by employing the real option method and the free cash flow to firm method in Indonesia Stock Exchange.

Partial significance test was made to find out whether an independent variable individually had a significance impact on a dependent variable. The impact of the independent variable on the dependent variable in the hypothesis would be tested with the reliability level of $90 \%$ or $\alpha=10 \%$. The criterion of partial test was as followed:
$H_{0}: \quad \beta_{\mathrm{j}}=0 ; j=0,1, \ldots, p:$ (asset, debt, tenor, implied volatility, Jakarta Inter Bank Offering Rate, public and equity) partially did not have influence the tendency of initial share price to undervalue or overvalue, by employing the real option me-thod and the free cash flow to firm method in Indonesia Stock Exchange.

Futher, $H_{1}: \beta_{j} \neq 0 ; j=0,1, \ldots, p:$ (asset, debt, tenor, implied volatility, Jakarta Inter Bank Offering Rate, public and equity) partially influenced the tendency of initial share price to undervalue or overvalue, by employing the real option method and the free cash flow to firm method in Indonesia Stock Exchange.

To find out the dominant variables in predicting the tendency of initial share price to undervalue or overvalue, we used odds ratio by examining $\beta$ exponent. The odds ratio equation was as followed:

odds ratio $=\left(\frac{P_{t}}{1-P_{i}}\right)=e^{\beta_{i}+\sum_{j=1}^{k} \beta_{2} X_{i j}}$

\section{RESULT OF THE STUDY AND DISCUSSION}

From the calculation by the free cash flow to firm method we found that 39 emitents experienced undervalue, 13 emitents experienced overvalue and two emitents experienced fairly price in pre-listing predicted price by the free cash flow to firm method. With the real option method we found that 47 emitents experienced undervalue and seven emitents experienced overvalue.

\section{Logit Model}

To analyze the factors which significantly influenced undervalue and overvalue, we used logistic regression analysis. The independent variables employed in this study were asset, debt, implied volatility, JIBOR, sheets of share, and equity. The dependent variable was the initial share price of emitents which were registered in Indonesia Stock Exchange during year 2008-2012. This dependent variable was expressed as a variable with the value of 1 (one) if the initial share price experienced overvalue, and 0 (zero) if the initial share price experienced undervalue.

\section{Free Cash Flow to Firm}

The model of share price prediction was: $L=\ln (p / 1-p)=0.156$ Equity $(0.100)+0.000$ Asset (0.508) - 0.016Debt (0.388) + 0.361Tenor (0.011) -0.008 Jibor $(0.974)-0.411$ Sheets of share $(0.634)$ +1.026 Volatility (0.284) - 1.043Dummy (0.087) 
From this equation we found that there were two variables which had positive and significant impacts, namely tenor and equity. One variable had a negative and significant impact, namely dummy. The parameter which showed the ability of the independent variable to explain the dependent variable was $R^{2}$. The $R^{2}$ value for the logit model of free cash flow to firm obtained was 0.577 , which meant that the ability of the eight independent variables to explain the initial share price tendency to overvalue or undervalue was 57.7 percent and there were 42.3 percent other factors outside the model.

\section{Real Option}

The model of share price prediction was:

$L=\ln (p / 1-p)=0.02$ Equity $(0.899)+0.000$ Asset

(0.098) - 0.009 Debt (0.668) + 0.349 Tenor

(0.040) - 0.053 Jibor (0.850) - 2.252 Sheets of

share $(0.016)+2.165$ Volatility $(0.068)-0.465$

Dummy (0.649)

From this equation we found that there were three variables which had positive and significant impacts, namely asset, tenor, and implied volatility. And there was one variable which had a negative and significant impact, namely sheets of share variable. The parameter which showed the ability of the independent variable to explain the dependent variable was $R^{2}$. The $R^{2}$ value for the logit model of real option was 0.754 , which meant that the ability of the eight independent variables to explain the initial share price tendency to overvalue or undervalue was $75.4 \%$ and there were $24.6 \%$ other factors outside the model.

\section{Discussion on the Study Result about Share Price Prediction}

The result of the exploration on the equation of share price prediction was shown in Table 2. According to the result of logistic regression analysis, the interpretation of odds ratio on the FCFF model for each variables was that each raise of one unit of independent variable would impact the equation as the percentage of the odds ratio shown in Table 2, with the assumption that the value of the other variables remained the same.

In the logistic regression model above, the variable which had the biggest impact was the volatility variable. The interpretation was that one point raise of volatility, with the assumption that the other variables remained the same, would have a positive impact on the equation $(73.61 \%)$, or a tendency to overvalue. The equity, asset, tenor, and JIBOR varia- bles had positive impacts which were respectively $53.89 \%$; $50 \% ; 58.92 \%$ and $49.8 \%$, which tended to overvalue, while the debt, sheets of share, and dummy variables had negative impacts which were respecttively $49.6 \% ; 39.86 \%$ and $26.05 \%$, which tended to undervalue.

Table 2. The Result Recapitulation of the FCFF and RO Models

\begin{tabular}{lrr}
\hline & FCFF & RO \\
\hline Hosmer and Lemeshow Test & 0.258 & 0.432 \\
Nagelkerke R Square & 0.577 & 0.754 \\
Accuracy of the Model & $83.30 \%$ & $90.70 \%$ \\
\hline Odds Ratio & & \\
\hline Equity & 53.892 & 50.500 \\
Asset & 50.000 & 50.000 \\
Debt & 49.600 & 49.775 \\
Tenor & 58.928 & 58.638 \\
Jibor & 49.800 & 48.675 \\
Sheets of share & 39.867 & 9.518 \\
Volatility & 73.614 & 89.706 \\
Dummy & 26.057 & 38.580 \\
\hline
\end{tabular}

In the real option model, the interpretation of odds ratio for each variables was that the variable which had the biggest impact was the volatility variable. If there was one point raise in volatility variable, the tendency to overvalue was $89.70 \%$, with the assumption that the other variables remained the same. The equity, asset, and tenor variables had positive impacts which were respectively $50.5 \%$; $50 \%$ and $58.63 \%$, which tended to overvalue, with the assumption that the other variables remained the same. The debt, JIBOR, sheets of share, and dummy variables had negative impacts on the equation which were respectively $49.77 \%$; $48.67 \% ; 9.51 \%$ and $38.58 \%$, which tended to undervalue.

1. Equity

From the results of logistic regression analyses using the two methods, we found that equity value had positive impact. The higher the equity value, the greater the tendency of initial share price to overvalue. In the free cash flow to firm method, equity had a positive and significant impact.

This conclusion agreed with the conclusion of Almilia \& Sulistyowati (2007) who stated that equity had a positive impact on share price. This could happen because some investors used book value of equity as consideration when they were making decision to invest, while in the real option method, this variable was not significant in the real level of $10 \%$, as studied by Yolanda (2009), which showed that equity did not have a significant impact. 
2. Asset

The result of logistic regression test in the real option method showed that asset value had a significant impact, but this impact did not greatly influence share price. This conclusion was in accordance with the studies of Andi (2010) and Hakiman (2005) which showed that asset had an impact on share price.

3. Debt

In both models we found that debt variable had a negative impact on the tendency of initial share price to undervalue or overvalue, but not significantly. This conclusion was similar to the conclusions of Hakiman (2005), Andi (2010), Alyahyaee et al. (2013) and Suharyadi (2010), who stated that debt variable had a negative impact on share price. This negative impact was natural since the increase of debt would cause financial distress. As proposed by Haryetti (2010), financial distress could cause bankruptcy and decline of company value (Sujoko \& Soebiantoro, 2007).

4. Tenor

The result of logistic regression analyses using the two methods showed that tenor variable had a real impact on initial share price. The positive coefficient value indicated that the longer the duration of tenor (debt), the initial public offering tended to overvalue. If tenor variable raised one point, the tendency to overvalue was $58 \%$. This conclusion agreed with the studies of Hakiman (2005), Setyabudi (2008), and Andi (2010) who stated that debt with long tenor duration would raise the share price of a company since tenor value would cause debt instrument to become sensitive to the change of the company value (Soliha \& Taswan, 2002).

5. JIBOR

The result of logistic regression analyses using the two methods showed that JIBOR variable did not have a significant impact on the tendency to undervalue and overvalue because, according to Hakiman (2005), JIBOR variable was an external variable so the involved parties could not influence it. JIBOR interest rate was the interest rate of debt among banks in Jakarta. This conclusion was in accordance with the studies of Permana (2008) and Liauw \& Wijaya (2013), who stated that JIBOR interest rate had a negative impact on share price.

6. Sheets of Share

The result of logistic regression analyses using the two methods showed a negative and significant relationship for the real option method. This conclusion agreed with the studies of Hakiman (2005), Bahsoon \& Emmerich (2003), Suharyadi (2010), and Andi (2010). This meant that one point raise in sheets of share variable would cause the tendency to undervalue as much as $9.51 \%$ for real option method and $39.86 \%$ for free cash flow to firm method, or the larger the number of share sheets issued by an emitent to the public, the greater the tendency of the emitent's share price to undervalue.

7. Implied Volatility

In both models implied volatility had a positive impact, and in real option model implied volatility had a significant impact. The greater the volatility of the share price, the greater the tendency of the share price to overvalue. This conclusion was similar to the conclusions of Hakiman (2005), Setyabudi (2008), and Ani (2010).

8. Dummy

The dummy crisis variable was put in the share price prediction model to measure the effect of global monetary crisis. The result of logistic regression analyses using the two methods showed a negative and significant relationship in the free cash flow to firm model. In this model, the dummy variable was negative and significant, which indicated that there was an impact from the time before the monetary crisis and the time after the monetary crisis. The global monetary crisis in year 2008-2009 was given the dummy number of 1 (one) and the time after the monetary crisis was given the number 0 . In the equation, the negative sign meant that the monetary crisis caused share price to tend to undervalue.

The ability of the free cash flow to firm method to predict was $83.30 \%$, and there were three significant variables, namely tenor, equity, and dummy. The ability of the real option method was $90.7 \%$, and there were three significant variables, namely tenor, implied volatility, sheets of share. From these facts we concluded that the model that would better benefit the prediction of share price in initial public offerring was the model with real option method.

The real option method had a better prediction ability (90.7\%), and the variable which had the biggest impact on the method was implied volatility, followed by JIBOR, debt, asset, equity, tenor, dummy, and sheets of share. Equity, tenor, and volatility variables had positive impacts, while debt, JIBOR, sheets of share, and dummy variables had negative impacts.

\section{Managerial Implications}

Based on the analysis result of the valuation of initial share price using the free cash flow to firm method and the real option method in Indonesia Stock 
Exchange during year 2008-2012, the managerial implications which can be put forward to be taken for considerations by companies who plan to carry out initial public offering, and to predict whether the initial share price tend to undervalue or overvalue, are:

The chief aim of a company is to maximize profit (Pujiati, 2012). The real option method is offered as a strategy in predicting share price because this method has a higher precision in predicting share price. Fixing extremely low share price can cause loss of fund that might be gained by an emitent. Thus, if an emitent plans to publish new shares, he should make a more intensified share valuation to see the movement of the company's profit and loss, so that he can determine the price range of the shares that will be published.

To reach an optimal result in initial public offering, an emitent can use sheets of share variable and volatility variable in the real option method since those variables are internal and can affect share price well. Besides, those variables are reversal to each other. Public variable has a negative impact and volatility variable has a positive impact on share price, namely by minimizing the number of shares sold to the public and by converting debt to long duration debt.

For investors who plan to invest by buying shares in initial public offering:

1. In buying new shares, we suggest that investors use the FCFF method for valuating the shares since this method shows the fundamentals of the company (the company's value), and the result of the calculations in the study indicates that the FCFF method gives cheaper share intrinsic value than the RO method.

2. We can also use the real option method to gain benefit from the method. We can calculate the share price in initial public offering by the real option method and use the result of the calculation as a guide for buying shares in initial public offering. If the share price in initial public offering is higher than the calculation of the real option method, do not buy the shares. If the share price in initial public offering is lower than the calculation of the real option method, investor can buy the shares with consideration on the discount given by the emitent.

\section{CONCLUSIONS AND SUGGESTIONS}

Based on the analysis result of the valuation of initial share price using the free cash flow to firm method and the real option method in Indonesia Stock Exchange during year 2008-2012, we conclude that:
1. From the valuation using the free cash flow to firm method and the real option method, we found that there were 39 emitents who experienced undervalue, 13 emitents who experienced overvalue, and two emitents who experienced fairly price at pre-listing predicted price by using the free cash flow to firm method. In the real option method we found that there were 47 emitents who experienced undervalue and seven emitents who experienced overvalue.

2. The result of logistic regression in the free cash flow to firm method showed that as a whole the eight independent variables, namely equity, asset, debt, tenor, JIBOR, sheets of share, implied volatility, and dummy had significant impacts in explaining the initial share price in Indonesia Stock Exchange during year 2008-2012, and indicated that the tendency to overvalue or undervalue was $57.7 \%$ and there were $42.3 \%$ factors outside the model. Partially there were two variables which had positive and significant impact, namely tenor and equity. One variable had a negative and significant impact, namely dummy.

3 . In the real option model, the overall eight independent variables showed that the tendency of the initial share price to overvalue or undervalue was $75.4 \%$, and there were $24.6 \%$ factors outside the model. Partially, there were three variables which had positive and significant impacts, namely asset, tenor, and implied volatility. And there was one variable which had a negative and significant impact, namely sheets of share variable.

4. The ability of the free cash flow to firm method to predict was $83.30 \%$, while the ability of the real option method was $90.7 \%$. From these facts we concluded that the method which would better benefit the prediction of share price in initial public offerring was real option method.

5. We hope that future studies will explore valuation of share price using other methods than free cash flow to firm and real option methods. Future researchers can also take samples from banking industry, underwriter, or internet companies.

\section{REFERENCES}

Almilia, L. S. \& Sulistyowati, D. 2007. Analisa Terhadap Relevansi Nilai Laba, Arus Kas Operasi dan Nilai Buku Ekuitas pada Periode Disekitar Krisis keuangan pada Perusahaan manufaktur di BEJ. Proceeding Seminar Nasional.

Al-yahyaee K., Pham, T. M., \& Walter, T. S. 2013. The Form of Debt and Stock Returns: Empirical Evidence from Oman. International Journal of Economics and Finance, 5(7): 9-21. 
Andi, M. 2010. Analisis Peluang Kecenderungan Overvalue atau Undervalue Harga Saham Perdana Dengan Metode Real Option pada Bursa Efek Indonesia. Thesis. Medan: Universitas Sumatera Utara.

Bahsoon, R. \& Emmerich, W. 2003. ArchOptions: A Real Options-Based Model for Predicting the Stability of Software Architechtures. Proceedings of the Fifth Workshop on Economics-Driven Software Engineering Research, EDSER 5, held in conjunction with the $25^{\text {th }}$ International Conferenceon Software Engineering.

Daljono. 2000. Analisis Faktor-faktor yang Mempengaruhi Initial Return Saham yang Listing Di BEJ Tahun 1990-1997. Kumpulan Jurnal Simposium Nasional Akuntansi, III: 556-572.

Hakiman. 2005. Metode Penentuan Harga IPO di Bursa Efek Jakarta dengan Menggunakan Metode Real Option. Disertasi. Bandung: Universitas Padjajaran.

Haryetti. 2010. Analisis Financial Distress untuk Memprediksi Risiko Kebangkrutan Perusahaan (Studi Kasus pada Industri Perbankan di BEI). Jurnal Ekonomi, 18(2): 23-35.

Liauw, J. S. \& Wijaya, T. 2013. Analisis Pengaruh Tingkat Inflasi, Tingkat Suku Bunga SBI dan Nilai Tukar Rupiah terhadap IHSG di BEI, (http://eprints.mdp.ac.id/cgi/search/simple?q=tris nadi+wijaya\&_action_search=Search\&_action_ search=Search\&_order=bytitle\&basic_srchtype $=$ ALL\&_satisfyall=ALL, retrieved on October 1, 2013).

Manaster \& Koehler. 1982. The Calculation of Implied Variances from the Black-Scholes: A Note. Journal of Finance, 37(1): 227-230.
Permana, Y. 2008. Pengaruh Fundamental Keuangan, Tingkat Bunga dan Tingkat Inflasi terhadap Pergerakan Harga Saham. Jurnal Akuntansi, 3 (12): $1-6$.

Pujiati, D. 2012. Pengaruh Struktur Kepemilikan Terhadap Nilai Perusahaan: Keputusan Keuangan Sebagai Variabel Intervening. Jurnal Ekonomi Bisnis \& Akutansi Ventura, 12(1): 71-86.

Setyabudi, H. 2008. Real Option Valuation in Petroleum: Studi Kasus di EMP Malacca Strait Oilfeld. Thesis. Yogyakarta: Universitas Gadjah Mada.

Soliha, E. \& Taswan. 2002. Pengaruh Kebijakan Hutang terhadap Nilai Perusahaan Serta Beberapa Faktor yang Mempengaruhinya. Jurnal Bisnis dan Ekonomi, 9(2): 149-163.

Suharyadi, H. 2010. Penentuan Harga IPO dan Model Prediksi Harga Saham dengan Menggunakan Metode Real Option. Thesis. Bandung: Universitas Padjajaran.

Sujoko \& Soebiantoro U. 2007. Pengaruh Struktur Kepemilikan Saham, Leverage, Faktor Intern dan Faktor Ekstern terhadap Nilai Perusahaan. Jurnal Manajemen dan Kewirausahaan, 9(1): $41-48$.

Winarno, W. W. 2011. Analisis Ekonometrika dan Statistika dengan Eviews. Yogyakarta: UPP STIM YKPN.

Yolanda R. 2009. Pengaruh Laba Akutansi, Arus Kas Operasi dan Nilai Buku Ekuitas terhadap Harga Saham pada Perusahaan-perusahaan Manufaktur yang terdaftar di Bursa Efek Indonesia. Skripsi. Surabaya: Sekolah Tinggi Ilmu Ekonomi Perbanas. 